\title{
AN ADDITION TO THE STUDY OF CRIME OF ISIJA FERATAGIĆ ${ }^{2}$
}

ABSTRACT. This paper discusses the crimes against the Serbs of Mitrovica and the surrounding area, committed by the Albanian criminals, among whom Isija Feratagić stood out. His atrocities significantly affected the position of the Serbian population and often led them to leave their households and emigrate to the Kingdom of Serbia. Turkish authorities were often uninterested in preventing the Albanians incidents, and military interventions mostly escalated into a conflict between the army and the Albanians. Such a situation had a negative impact on the lives of Serbs, not only in Mitrovica and its surroundings, but also in the entire province of Kosovo. The Serbian people in Old Serbia, with the support of the Government from Belgrade and the representatives of Russia, sent complaints to the Turkish authorities and the Sultan in Constantinople countless times, as well as to the representatives of the great powers. Under their influence, the Porte was forced to accept the implementation of reforms. Isija Feratagić, who in his actions was guided by personal interests and the lowest impulses, was pushed into the background and is no longer found in the reports of the consuls.

KeYWoRDs: Serbs, Albanians, Isija Feratagić, Mitrovica, crimes, Turkish authorities.

\footnotetext{
vesna.zarkovic07@gmail.com
}

The work was created within the scientific research work of the NIO under the Agreement concluded with the Ministry of Education, Science and Technological Development number: 451-03-9 / 2021-14 / 200020 dated February 5, 2021.

This paper was submitted on September $16^{\text {th }}, 2021$ and accepted for publication at the meeting of the Editorial Board held on November $16^{\text {th }}, 2011$. 
The weakening of the Ottoman Empire at the end of the 19th and the beginning of the 20th century had a negative effect on the position of the Serbian population in the province of Kosovo. The actions of the Albanians, who were in close contact with the Turkish authorities, also contributed to the bad situation. That period of the history of Serbs in the area of Old Serbia was marked by numerous gatherings and organizations of the Albanians, their mutual conflicts, greed and struggle for supremacy. The further course of events and the influence on the actions of the Albanians was mainly a consequence of the Greco-Turkish war and the loss of Crete (Зарковић, 2014, pp. 123-135). Frustrated by the outcome of the war and its role in it, the Albanians decided to take a more intensive approach to protecting the borders of the Ottoman Empire. Many of them returned from the war with weapons and became more active in the province of Kosovo, committing atrocities at every turn and invading the territory of the Kingdom of Serbia (Зарковић, 2015, p. 80). The result of the war was largely reflected in the feudal lords who were worried about their financial situation, so they decided to organize and hold a meeting in Peć at the beginning of $1899 .{ }^{3}$ The Albanians had great support from Austro-Hungary, which presented itself as the only one capable of protecting their interests in the Balkans in the event of the disintegration of the Turkish rule. That is why, through Hadži Mula Zeka from Peć, the chairman of the gathering, and Riza beg Kruezi from Đakovica, it tried to link the interests of Albanians circles from Old Serbia and Macedonia to the politics of Vienna. Austro-Hungary became the main protector of the Albanians from the province of Kosovo and encouraged them to spread powerlessness, oppose the Turkish authorities and confront the Serbs (Батаковић, 1991, pp. 93-94).

The activities of the Albanians intensified and were accompanied by more frequent and stronger attacks by their outlaws. At the end of January of the same year, an oath (besa) was established at the assembly for the entire province of Kosovo, and it was decided to stop the public killings. Despite this fact, the Serb population continued to be exposed to various atrocities and killings. The fines came to the fore, followed by various pressures, which influenced the increase in the number of emigrants who found refuge in Serbia. The entire province of Kosovo had become a training ground for daily Albanians actions directed against Serbs, both those who

3 About the Albanians gathering in Peć in detail: Зарковић, 2015, p. 79-92. 
lived in rural areas and those in cities. All the villages, all the towns and small cities in Old Serbia, inhabited by Turks and Albanians, as well as mixed areas, had numerous thugs who stood out for their crimes. One of those, among others, who influenced the events in Mitrovica and its surroundings, was Isija Feratagić.

The event in Mitrovica, which followed immediately after the gathering in Peć, reflected the situation and the mood of the Albanians in the entire province of Kosovo. The main actor was Isija Feratagić, on whom the fate of the Serbian population in the city and its surroundings depended. On the evening of January $26,1899,{ }^{4}$ four Christians from Mitrovica, two of them in disguise, went to a friend's house. Tirče Sotirović, Vlach from Kruševo, Ljubomir N. Marković and Gligorije Kostić from Peć and Dimče the tailor from Veles lived as singles in a house that was 200 to 300 steps away from the place where the gathering was held. On the way, they were intercepted by a police patrol led by onbaşı (corporal) Mehmed. Although he knew them, his suspicion was fueled by disguise, so he led them to kaymakam (mayor). During the time when they were staying in the building of the hućumat (municipal building), the onbaşl, in order to gain importance, spread stories around the city that soon reached the Mitrovica Mohammedans. There were two versions: first he said that he caught disguised Chetniks from Serbia with bombs that they intended to throw in the mosque and burn the whole town, and then he stated that he caught some Serbs wearing veils with the idea of entering harems and scaring women. Such stories provoked anger among Mitrovica's Mohammedans, who, led by Isija Feratagić, broke into the kaymakamat building and killed Gligorije Kostić. The other three fled upstairs and managed to escape death thanks to the kaymakam (mayor) who handed them over to the army for safekeeping. Gligorije Kostić was killed in the cruelest way, by Isija firing six bullets, crushing his head, and then the others shot and stabbed him until his brain and broken ribs were ripped open. The anger of the Albanians led by Isija Feratagić and the brutal murder of Kostić caused dissatisfaction and fear among the Serbian population, especially the fact that the murdered man was not buried according to Orthodox customs. Mutasarrif from Priština did not allow the Orthodox priest to perform the funeral service in the church, but the deceased was buried without the presence of any Serbs.

4 The dates are provided according to the old calendar, as stated in historical sources. 
Isija Feratagić was dissatisfied with the outcome because three Serbs survived, and thanks to the messengers, he managed to gather around 3,000 armed Albanians in Mitrovica the next day, who demanded that the kaymakam hand over the prisoners to them. Otherwise, they threatened to massacre Serbs in and around the city. The situation in Mitrovica was tense, so the Priština mutasarrif arrived in the town on the same day. The next day, January 28, the vali arrived with reinforcements. His stay in the city was marked by negotiations with the leaders of the Albanians, who were gathering in Priština. ${ }^{5}$ As the result of these negotiations, the kaymakam, who protected the Christians, was dismissed which to some extent satisfied the dissatisfied Mohammedans (Peruničić, 1985, p. 340). After leaving Mitrovica, the vali entrusted the maintenance of order to the local Albanians tyrants, among whom Isa Boljetinac was in the lead. With vali's departure, the army withdrew from Mitrovica. Their departure from the city influenced the Albanians to organize and gather in groups that controlled the situation in the town. The situation was more serious than expected, and according to the opinion of the Consul of the Kingdom of Serbia in Pristina, Svetislav Simić, there was a possibility that it could be transferred to other parts of the Kosovo vilayet (province), because some Mitrovica residents left their homes and left the city. The Turkish authorities were powerless before the Albanians who did not intend to give up their demands and threatened to slaughter the Serbs. Consul Simić believed that the Mitrovica event should not be pushed into the background, but exploited in favor of earlier complaints. He was also of the opinion that Kostić's murder and Albanians' attitude towards the Serb population and the Turkish authorities were closely connected with the decisions of the assembly in Peć. ${ }^{6}$

The situation in Mitrovica and the event initiated by Isija Feratagić required additional engagement of the Turkish authorities and

5 Archives of Serbia (= AS), Ministry of Foreign Affairs (= MID) Political-Educational Department (= PPO), 1899, line 173 (III), Pov. № 60, Consul M. Kurtović V. Đorđević, Minister of Foreign Affairs, Skopje, February 7, 1899 (This document has not been preserved in its entirety); Archives of Serbia (= AS), Ministry of Foreign Affairs (= MID) Political Department (= PO), 1899, roll 201, A/21, fasc. And, dos. III, Consul S. Simić - Minister of Foreign Affairs, Skopje, January 31, 1899; AS, MID PO, 1899, roll 201, A/21 fasc. And, dos. IV, Pov. № 42, Consul S. Simić - S. Lozanić, Deputy Minister of Foreign Affairs, Priština, February 17, 1899; Peruničić, 1985, p. 330, 337-339; Јагодић, 2009, p. 56.

6 AS, MID PO, 1899, roll 201, A/21, Pov. № 27, Consul S. Simić - V. Đorđević, Minister of Foreign Affairs, Priština, February 2, 1899; Peruničić, 1985, p. 341. 
influenced the Sultan to decorate the Kosovo vali and the Priština mutasarrif. In Constantinople, more care was taken to calm down the situation, which was in line with the Sultan's February orders; not much attention was paid to the fact that those orders were not carried out in practice by the authorities, but by the leaders of the Albanians. Mitrovica was full of armed Albanians, who, when they meet an army patrol on the street, mockingly ask if they are sorry that they also carry weapons, urging them to take it from them, if they are sorry (Јагодић, 2009, p. 57 Peruničić, 1985, p. 380). The armed Albanians who walked freely around the town caused fear and unrest among the Serb population. The resulting situation led them to send a request to Sultan Abdul Hamid in mid-February 1899. The members of the church municipality, led by the president, Archpriest Jovan Simić and several citizens, clearly pointed out the insecurity and misfortunes that befell them, especially emphasizing the event in which Gligorije Kostić died. Their fear was justified, personal and property security was endangered, because the Albanians who caused the riots and committed the crime went unpunished and continued to walk around the city. ${ }^{7}$ The army was sent to Mitrovica, but the situation did not improve. The Albanians and the Turks from Mitrovica often gathered and made agreements, which reminded the Serbs of an unpleasant event. Wealthier Serbs fled the city, and others who were unable to leave found themselves in a precarious situation and in constant fear. In a report sent to the Minister of Foreign Affairs in Belgrade, Consul Svetislav Simić, based on the information received from his commissioner, described the situation in the following words: "No two Serbs can be seen anywhere"8. The situation in Mitrovica was transferred to other parts of the province of Kosovo. The killings were more frequent and caused fear, even among the Turks, of their consequences, while the Serbs, in fear, stopped all activities and closed their shops. Turkish authorities tried to restore order and issued an order for a six-month prison sentence for any individual who came to town with a knife and armed, but Mitrovica Serbs continued to fear a possible massacre. The fear was intensified by the fact that the vali, returning to Skopje, left the town in the trust of Isa Boljet-

7 AS, MID PO, 1899, roll 201, A/21, Transcript of the application of the members of the Municipality and the citizens of the town of Mitrovica to Sultan Abdul Hamid, Mitrovica, 15 February 1899; Peruničić, 1985, p. 357.

8 AS, MID PO, 1899, roll 201, A/21, № Pov. № 28, Consul S. Simić - V. Đorđević, Minister of Foreign Affairs, Priština, February 5, 1899; Peruničić, 1985, p. 361. 
inac $^{9}$ and Ferhat Alidragić, well-known villains. The Mitrovica event best illustrates the nature of the relationship between the Turkish authorities and the Albanians, as well as the weak foundation on which the public order in the province of Kosovo rested. For these reasons, the Serbs had in mind that an incident could be caused at any moment, which would culminate and lead to a real massacre. Fearing for the future and security of the Serbian population, Consul from Pristina Svetislav Simić believed that the European and Serbian press in Belgrade did not pay attention to the Mitrovica event and that the public was informed about it only from Turkish sources. ${ }^{10}$

Promises coming from the Turkish side that order would be restored did not yield results on the ground. While the reaction of the vali was expected, the Albanians did not stop persecuting the Serbs. One of those persecuted was Jerotije Jorgić, an old man from Mitrovica who was sentenced to two years in prison without any guilt during the operation of the military court in the -80s. Poor prison conditions left consequences to his health, so he had to stop his shoemaking business and open a retail store. The trade brought him a solid income, but after the Mitrovica event in January, he had to close the shop, which was located in a beautiful place. The reason for the closure was Isija Feratagić, who, although without any trade, intended to open a meathouse. Feratagić demanded that he hand over the shop to him, but Jorgić said several times that he had nowhere to go and that his house was just behind it. Not wanting to listen to any excuse, Feratagić remained persistent in his intention and first tore off Jorgić's mustache in front of a Turk, and then, threatening with a knife, demanded that he hand over the shop to him. The blackmailed man managed to escape and went to the village of Boljetin with the intention of seeking the protection of Isa Boljetinac. As he did not find him in the house, he went to Vučitrn with the same goal to beg for the help, through Jerga Ćamilović, from the Albanians from the tribe of Madžuni. When that did not work out for him either, he extended his trip to Priština, where the Serbian consul advised him to try again and seek the help of Boljet-

9 Until the famous Mitrovica event, Isa Boljetinac was considered a friend and protector of the Serbs, but later he became a villain by whose hands many innocent people died (Зарковић, 2021, p. 431).

10 AS, MID PO, 1899, roll 201, A/21, Pov. № 36, Consul S. Simić - S. Lozanić, Deputy Minister of Foreign Affairs, Priština, February 10, 1899; Peruničić, 1985, p. 363365. 
inac. ${ }^{11}$ While Jerotije Jorgić was staying in Priština, his wife and children complained to the kaymakam in hućumat, who promised them help. In order to fulfill his promise, he called Isija Feratagić and demanded that he not touch Jorgić. Although he made a promise to kaymakam, Feratagić spoke loudly in the bazaar: "If I had known he was calling me for that, I would not have gone to him."

Isija Feratagićs only occupation was harassing Serbs, so he immediately found a new victim. The next in line was Dušan Sterđević, a goldsmith from whom he demanded to pay him five liras in gold, otherwise he threatened to kill him. Pressed by Feratagic's threats, Dušan went to Skopje. After that, kaymakam was faced with new complaints presented by Trifun Popadić and Milutin Sterđević. They were promised help in the conversation, but on the condition that they do not bow to either side. In Mitrovica itself, the Turks were divided into two groups: one was led by Ali Draga's sons, to whom Isa Boljetinac also belonged, while the other approved of oppression and was gathered around Isija Feratagić. The consul from Priština was of the opinion that the first side was more favorable for the Serbs at that time, and he was thinking of organizing a visit of prominent Mitrovica Serbs to the vali, in which they would acquaint him in detail with the crimes of Isija Feratagić. At that moment, it was obvious that the authorities were powerless and indecisive to take any action against Feratagić and other oppressors. ${ }^{12}$

The protection that the influential Albanians provided to Serbs in numerous situations until then was lacking, and the number of armed criminals in Mitrovica was increasing. Thus armed, they passed freely by the police patrol and made the town even more insecure for life. Compared to Vučitrn, Mitrovica has become a place where daily oppression took place in the plain view of the authorities and the army. The Albanians did not respect any decisions of the authorities, as evidenced by the fact that Isija Feratagić, without anyone's approval, released some Turkish young men who had been arrested a few days earlier. Familiar with these events, Consul Svetislav Simić decided to realize the idea that representatives of Serbs from Mitrovica visit the vali in Skopje. ${ }^{13}$ At his insist-

11 AS, MID PO, 1899, roll 201, A/10, Pov. № 62, Consul S. Simić - V. Đorđević, Minister of Foreign Affairs, Priština, March 11, 1899; Peruničić, 1985, p. 379-381.

12 AS, MID PO, 1899, roll 201, A/10, Pov. № 86, Consul S. Simić - V. Đorđević, Minister of Foreign Affairs, Priština, March 29, 1899; Peruničić, 1985, p. 396-397.

13 AS, MID PO, 1899, roll 201, A/10, Pov. № 62, Consul S. Simić - V. Đorđević, Minister of Foreign Affairs, Priština, March 11, 1899; Peruničić, 1985, p. 379-381. 
ence, the delegation led by the seventy-year-old archpriest Jovan Simić traveled to the vali. In addition to the archpriest, the members of the deputation were: Janićije Slavković, a priest from Mitrovica, Milutin Sterđević and Raka Krstić, merchants. They were joined by Dušan Sterđević, a goldsmith, and Jerotije Jorgić, also traders, who suffered great terror from the Albanians villains. With the recommendation of the Russian consul Viktor Mashkov, they presented the problems they faced every day, especially those that came from Isija Feratagić. The vali, as many times before, promised to settle the situation in Mitrovica, warning them not to mention their visit to anyone. ${ }^{14}$ Although the army was deployed in the town, the Albanians obviously had the control. In the first half of 1899 , there were three infantry battalions, a cavalry squadron and one artillery battery in Mitrovica. The majority of the army was housed in a beautiful and spacious barracks on the plateau above the town, while the other part was located on the border and around the town. Weapons, ammunition and other military equipment were distributed from Mitrovica to Novi Pazar, Prijepolje, Sjenica, Bijelo Polje, Peć, Đakovica, and Berane. ${ }^{15}$

In the conversation with the delegation of Mitrovica Serbs, the governor (vali) did not give any concrete promise, except for the remark that he was acquainted with all the events in the city. He emphasized that he had plans to restore order and suggested that the victims pay the criminals the requested amount, which would be reimbursed later. However, he did not order that five lira be paid to them at that time in the name of a fine to Isija Feratagić. It was clear to the Serbs that the governor was not ready to take decisive steps, contrary to earlier stories. He claimed that he would calm down the Albanians with the help of the army, but he was contradicted by the fact that troops had already been deployed in the city. According to the Serbian consul from Priština, all that was needed was the determination of the authorities to arrest and punish Isija Feratagić and other criminals according to the law. However, it was obvious that the vali was not ready to take such a step that would lead to a conflict with members of Feratagić's fis (tribe) and the rest of the Albanians. In that case, an authorization was needed to take energetic measures, which he did not have from Constantinople.

14 AS, MID PO, 1899, roll 201, A/10, Pov. № 91, Consul S. Simić - V. Đorđević, Minister of Foreign Affairs, Priština, March 2, 1899; Peruničić, 1985, p. 378-379.

15 AS, MID PO, 1899, roll 201, A/10, Pov. № 74, Consul S. Simić - V. Đorđević, Minister of Foreign Affairs, Priština, March 24, 1899; Peruničić, 1985, p. 383. 
Precisely in that fact lies the cause of such behavior and favoring of the Turkish authorities towards the Albanians, whose victims were the Serbs. ${ }^{16}$

After the return of the delegation of Mitrovica Serbs from Skopje, the pressure on the local population did not stop. With the help of local tyrants, the police authorities extorted a statement from the prosecutor that there was peace in the town and that no one was disturbing them. Jerotije Jorgić was summoned to hućumat with a request to sign and certify the offered statement, but he refused. However, his decision was followed by pressure from the well-known tyrant Isija Feratagić, and then by one police officer, which resulted in stamping the already written statement. For Consul Svetislav Simić, such pressure was a plan for establishing order, which the governor talked about in a conversation with the Mitrovica delegation. That is why he advised Jorgić to take the first train to Skopje and introduce the vali and the Russian consul to the forced extortion of signatures. ${ }^{17}$ Frequent complaints from the Serbian side, as well as the visit of the consul from Priština, influenced the vali, for the first time, since he performed that duty, to visit the places in Kosovo where the tyranny of the Albanians culminated. His visit was also a consequence of the protests sent directly to the Sultan, as well as the press in Serbia, which more often wrote about the position of Serbs in Kosovo. ${ }^{18}$

Turkish authorities promised to stop the anarchy, which was gaining momentum. However, the actions of their representatives on the ground were in complete contradiction with the promises. This is clearly shown by the case of Dimitrije Nedeljković, who was often harassed by Isija Feratagić. Due to the frequent complaints of the endangered, the police were sent to protect him. Although they were accommodated in his house, instead of preventing violence and capturing Feratagić, the police, with the help of Vučitrn aghas, forced Nedeljković to reconcile with him. In addition, they suggested to him to pay 16 liras, entertain Isija nicely and take him as the guardian of his household. ${ }^{19}$

16 AS, MID PO, 1899, roll 201, A/21, Pov. № 94, Consul S. Simić - V. Đorđević, Minister of Foreign Affairs, Priština, April 5, 1899; Peruničić, 1985, p. 416.

17 AS, MID PO, 1899, roll 201, A/21, Pov. № 103, Consul S. Simić - V. Đorđević, Minister of Foreign Affairs, Priština, April 9, 1899; Peruničić, 1985, p. 421-422.

18 AS, MID PO, 1899, roll 201, A/21, Pov. № 130, Consul S. Simić - V. Đorđević, Minister of Foreign Affairs, Priština, April 30, 1899; Peruničić, 1985, p. 432. 
An aggravating circumstance for the Serb population was the collection of fine in the amount of ten percent, which was mostly taken in rich villages. It was collected by the strongest instigators of the anarchic state, who appointed people without any moral scruples to take the monies. They tried to collect as much as possible from reaya (oppressed people), because they themselves benefited. In the villages of Mitrovica, this money was collected by Isija Feratagić, whose actions reflected on the economic side of the Serb čifciijas (land beneficiaries) and brought them into an unenviable financial situation. It was another type of pressure on the Serb population of Mitrovica and the surrounding area. ${ }^{20}$

Economic pressure was accompanied by other atrocities. Women and girls were attacked by Albanian villains. An event that took place in mid-September 1901 in Mitrovica was recorded. The outlaws, Mehmed Mustafić, the son of the Mitrovica chief Mustafa Aga, Isija Feratagić and two other Albanians tried to rape and convert a Serb woman in her house. This crime was prevented thanks to the quick reaction of the neighbors and the security patrol that clashed with the attackers. Mehmed Mustafić was killed in the conflict, whose father, accusing the authorities, together with Šaban Kopriva gathered about 1,000 Albanians and threatened to attack the city. The gathered mass was opposed by the army led by the Mitrovica military commander Šemsi paša, and after a minor conflict, the attackers fled. Mustafa aga, Isija Feratagić and Šaban Kopriva first fled to Drenica, to the village of Prekaze, from where they went in different directions. The first went to Đakovica kaza, the second to Lab, while the third was not known where he took refuge. Šemsi paša went after the tyrants to Drenica, and then to Peć kaza. In this military action, he arrested some villains, among them Šaban Kopriva, and destroyed several towers. However, he did not have the authority from Constantinople to fully use force, but the order to treat the rebels more moderately. The attitude they had towards the Albanians in the capital influenced the release of all those arrested, and Mustafa Aga, Isija Feratagić and Šaban Kopriva were no longer prosecuted (Јагодић, 2009, р. 71; Стојанчевић, 1994, p. 219).

19 AS, MID PPO, 1900, line 22 (II), no number, Excerpt from a report from Priština, 22 January 1900; Same, Pov. № 60, Consul S. Avramović - S. Novaković, Minister of Foreign Affairs, Priština, March 13, 1900.

20 AS, MID PO, 1899, roll 201, A/21, Pov. № 335, Consul S. Simić - V. Đorđević, Minister of Foreign Affairs, Priština, September 13, 1899; Peruničić, 1985, p. 495. 
In September 1899, by a general agreement of the Mitrovica leading citizens, a decision was made that weapons may not be carried in the town. At the beginning of the same year, after the murder of Gligorije Kostić, the reputation of the government, which more visibly favored the Albanians, declined. Due to the fear of major incidents, a policy of concessions was pursued, even in those situations when it was a matter of minor incidents. Although the decision to ban the carrying of weapons in Mitrovica was in force, it was not possible to restore the old situation. ${ }^{21}$

Until the beginning of 1899, the relations between Mitrovica's Mohammedans and Serbs were not so bad, but since then the intolerance of the former towards the latter had become unbearable. At the end of the 19th and the beginning of the 20th century, Mitrovica began to develop rapidly thanks to the railway that started from Thessaloniki. The entire trade of the northwestern part of the province of Kosovo took place through Mitrovica, where representative offices of numerous companies were opened, which led to the formation of a strong colony of traders who arrived from other places. One of the most numerous trade and craft colonies consisted of the people of Peć, who, in addition to searching for new jobs and income, fled from Metohija where the tyranny of the Albanians was unbearable. One of the most prominent Serbs in Mitrovica at that time was Đorđe Sterđević, a goldsmith, a member of the numerous trade and craft colony of Peć inhabitants. Although he was born in Peć, as a child he moved to Prizren, where he learned the craft of goldsmithing and developed his business. His son Dušan also joined the business, and he moved to Mitrovica in 1895 due to pressure from the Albanians. ${ }^{22}$ Đorđe was characterized by courage and determination not to retreat before the Turkish and Albanians tyrants. The traits that adorned him aroused the hatred and intolerance of fanatical Mohammedans. Abdurahman, a tobacconist from Mitrovica, owed a small sum of money to Sterđević, which he demanded several times. At the request to return the money, there was a conflict between the two in Abdurahman's shop. Not wanting to settle the debt, Abdurahman responded with curses and, utter-

21 AS, MID PO, 1899, roll 201, A/21, Pov. № 347, Consul S. Simić - V. Đorđević, Minister of Foreign Affairs, Priština, September 29, 1899; Peruničić, 1985, p. 505.

22 AS, MID PPO, 1901, line 28, PP № no number, consul S. Avramović - M. Vujić, Minister of Foreign Affairs, Priština, June 29, 1901; Ibid., PP № 446, Consul S. Avramović - M. Vujić to the Minister of Foreign Affairs, Priština, June 1, 1901; Секулић, 2005, p. 262. 
ing derogatory words, he began to pluck Đorđe's mustache. The assailant retaliated with a blow and filed a lawsuit in hućumat the next day. The fact that Đorde had the courage to resist the Turk offended many tyrants, especially Isija Feratagić, who had intended to kill his son two years earlier. On October 9, 1901, exactly at noon, while the bazaar was full of people, Feratagić visited Sterđević in his shop. Without any reason, he fired one bullet from a martini gun from close range, followed by three shots from a revolver. He walked calmly out of the shop and, after kidnapping a horse from a Mohammedan trader, he headed in the direction of the hućumat, fired several times and provoked the police (zaptieh) to arrest him. A patrol of five soldiers, led by zaptieh onbaşı Mehmed, was a few steps from the place of the murder, but did not react, which enabled the killer to escape. It seemed as if the police had served Feratagić to escape from the city. Isija took refuge in his tower, and after a few hours, a yüzbaşı came, but did not arrest him. Two days later, accompanied by ten of his men, Isija attended a wedding in the village of Vinarce and no one was looking for him. Isija Feratagić was not satisfied only with the murder of Đorđe, but his men ambushed his son Dušan, who was staying in Pazar. The return in the late evening saved Dušan from certain death, because the conspirators withdrew, thinking that he would not come that day. ${ }^{23}$

The murder of Đorđe Sterđević left a strong impression and enthusiasm among the Turks of Mitrovica, and Isija was praised, calling him 'bizim arslan' (our lion). They used this opportunity to declare their loyalty to the Sultan and take revenge on kaymakam, certain officials of the hućumat and on yüzbaşı towards whom they showed intolerance, considering them the main culprits who demanded that the famous villains of Mitrovica and its surroundings be called to Constantinople. That is why they immediately sent a statement to the Sultan stating that the situation was bad and they accused kaymak for that. The cunning of the Mitrovica Turks and the statement resulted in the change of kaymak. The situation in the city was aggravated by the return from exile of Šaban Kopriva, Šerif Kučica and Elez aga Mustafić. ${ }^{24}$

Isija Feratagić fled with his men in the direction of Kolašin, and the authorities did not even try to capture them. It was obvious that

23 AS, MID PPO, 1901, line 28, Pov. № 315, Consul S. Avramović - M. Vujić, Minister of Foreign Affairs, Priština, October 13, 1901.

24 AS, MID PPO, 1901, line 28, Pov. № 315, Consul S. Avramović - M. Vujić, Minister of Foreign Affairs, Priština, October 13, 1901. 
the Turks did not even think about his arrest. In the meantime, Mitrovica was visited by the representative of the representative mutasarrif, Ahmed paša, and the mufti of Priština. Although their appearance among the Serbs instilled hope that order would be restored, they did not take any measures to prevent anarchy and bring Isija to justice. After the visit of the representatives of the Turkish authorities, two chiefs from the Albanians Feratagic fis, Ram Ljutan from Drenica and Redžep Prekaza from Prekaze, came to Mitrovica. On behalf of the whole of Drenica, they offered the Sterđevic family compensation for the blood of the murdered Đorde in the amount of 1,100 dinars in gold. They also visited the hućumat, insisted that the majlis gather and stated that they would bring Isija to the bazaar, provided that no one was prosecuting him. They justified their demands by explaining that it was not Feratagić himself who killed Đorđe, but the entire Drenica arnautluk. The demands of the two citizens of Drenica were not accepted in the hućumat, but it was requested that the killer be brought. The conditions set by the hućumat provoked a reaction from Ram Ljutan, who replied indignantly: "Even if he came, he would be followed by a thousand of us, so let us see what you will do to him". ${ }^{25}$

The crime that happened provoked a reaction from the Turkish authorities, who sent Hamdi paša and Alai Beg, the commander of the gendarmerie from Skopje, to Mitrovica. While they were in the city, Isija Feratagić was seen in Vučitrn on October 17 as armed, on a white horse and accompanied by several of his supporter walks around freely. Consul from Priština Sima Avramović stated that Feratagić is charged with several murders, including those of Bećir aga Ćorović, Malić beg Prizrenac, zaptieh yüzbaşı, two dismissed soldiers from Sjenica, Gligorije Kostić and Đorđe Sterđević. Despite these allegations, Isija Feratagić continued to threaten Dušan and other Serbs not to press charges against him otherwise he promised that they would suffer the same fate as the murdered. This attitude of his had a foothold among Turkish officials with whom he was in close contact. Mehmed onbaşı is cited as support, whose words after Sterđević's murder additionally encouraged Feratagić. He addressed the murderer in the language of the Albanians: "Aferim, our hero! You whitewashed our cheeks for killing such an infidel"! 26 The close cooperation between the Turkish authorities and the villains of Albanians is reflected in the later decision of the Kosovo

25 AS, MID PPO, 1901, line 283 (IV), Pov. № 326, Consul S. Avramović - M. Vujić, Minister of Foreign Affairs, Priština, October 25, 1901. 
governor, who told Sterđević's widow that he was not allowed to arrest the killer. Justifying himself, the governor granted her a monthly pension and promised to provide free education to the son of the murdered man. ${ }^{27}$

The connection between Turkish officials and Albanian villains did not shake the Serbs, who continued to complain. They wrote a letter to the Kosovo vali and Mitrovica military commander Šemsi paša, and the Serbian municipality wrote a complaint to the Sultan, which was sent to Constantinople through the consul in Priština. The reaction from the Serbian side influenced Mehmed Aga Ćamilović, the president of the municipality in Mitrovica, to telegraph together with the mufti and several village mukhtars (stamps) to the Kosovo governor and emphasize that "the murdered Đorđe was an immigrant and was not a good man". Almost at the same time, a meeting of Turkish champions from Mitrovica was held in the house of Elez aga Mustafić, at which it was said that other respectable Serbs should be killed as well. ${ }^{28}$

The Serbs who, due to the nature of their work, had to leave the city daily, felt insecure on the roads. Among the many who found themselves in trouble was Trifun Popadić, a merchant from Mitrovica. It seems that his only guilt was the connection with the Russian consul Viktor Mashkov from Skopje, who baptized his daughter. Just at that time, Mashkov sent a report to his embassy in Constantinople, in which he emphasized that the Albanians oppressors, among them Isa Boljetinac and Isija Feratagić, are still at large. The engagement of the Russian consul led Feratagić to take revenge and he saw Popadić as the right opportunity. The words he uttered during the attack point us to this kind of thinking: "Let the Russian consul save you now". ${ }^{29}$ The carriage driver Rista Stanković testified at the consulate in Priština before Nastas Nastasijević about the unpleasant meeting with Feratagić and the capture of Popadić. He mentioned that Trifun Popadić was taken in the direction of the vil-

26 AS, MID PPO, 1901, line 28, Pov. № 324, Consul S. Avramović - M. Vujić, Minister of Foreign Affairs, Priština, October 19, 1901; Peruničić, 1988, p. 110; Секулић, 2005, p. 263.

27 AS, MID PPO, line 28, PP. no. 2891, Consul M. Kurtović - M. Vujic, Minister of Foreign Affairs, Skopje, November 1, 1901; Јагодић, 2009, p. 146.

28 AS, MID PPO, 1901, line 28, Pov. № 324, Consul S. Avramović - M. Vujić, Minister of Foreign Affairs, Priština, October 19, 1901.

29 AS, MID PPO, 1901, line 28, no. 2903, Consul M. Kurtović - M. Vujić, Minister of Foreign Affairs, Skopje, November 1901. 
lage of Prekaze, in the Drenica district. The Albanians hit him with rifles about ten times along the way. Upon his arrival in Mitrovica, Rista went to the hućumat and told everything to Šemsi paša, who swore in front of him that he would "catch Isa either alive or dead". Petar Popadić, the brother of the captured Trufun, to whom some things, a fez (cap) and a coat, were handed over, informed the consul in Priština about Feratagić's intentions. He stated that the villain demanded that he be forgiven for the murder of Đorde Sterđević and promised to release Trifun after that. ${ }^{30}$ In the meantime, the captured Popadić from Prekaze wrote to Živko Frtunić about the intentions of the Albanians to capture several more prominent Serbs from Mitrovica and Vučitrn. His findings came true because Isija Feratagić's company tried to capture Stojan, Prokopije Topalović's son, but he managed to escape and save himself. ${ }^{31}$

Šemsi paša was determined to deal with Isija Feratagić and his supporters, but he was afraid of the reaction of the Albanians from Drenica, ready to clash with the army. That is why he came up with the idea to hire Zejnul aga Šišković, the most prominent Albanians champion from Vučitrn and the richest in Kosovo, to peacefully free Popadić from captivity (Peruničić, 1988, p. 7). Feratagić granted the request of the respectable citizen of Vučitrn because he knew that his affection was in his favor and enabled him to continue staying in Mitrovica and avoid surrendering to the Turkish authorities. Therefore, on November 24, 1901, he released Popadić, who came to Vučitrn accompanied by his men, from where he went to Mitrovica. ${ }^{32}$

Isija Feratagić's expectation that the capture of Trufun Popadić would acquit him of the guilt for Sterđević's murder was not fulfilled. That is why he came up with the idea to catch the priest Arsenije Božović from Pridvorica, Kosta Jeremić from Brnjak, Milenko Đurić from Crepulja, and Zeko Vuksanović from Strmac. He was convinced that capturing respectable people would absolve him of guilt for the crimes he had committed. The plans of Isija Fer-

30 AS, MID PPO, 1901, line 28, Pov. № 323, Consul S. Avramović - M. Vujić, Minister of Foreign Affairs, Priština, November 4, 1901.

31 AS, MID PPO, 1901, line 28, Pov. № 344, Consul S. Avramović - M. Vujić, Minister of Foreign Affairs, Priština, November 23, 1901; Peruničić, 1988, p. 119.

32 AS, MID PPO, 1901, line 28, Pov. № 346, Consul S. Avramović - M. Vujić, Minister of Foreign Affairs, Priština, November 26, 1901; Peruničić, 1988, p. 120. 
atagic and his men instilled fear in the Serb population of the Mitrovica area. ${ }^{33}$

The tyranny continued and demanded greater involvement of Serbian diplomacy. At that time, the Serbian population of the province of Kosovo saw the only salvation in the Kingdom of Serbia, and that is why they addressed the Government in Belgrade with requests that its representatives in Constantinople work more actively to suppress oppression. On August 14, 1902, Prime Minister Mihailo Vujić ordered the Serbian ambassador to Constantinople, Sava Grujić, to ask the Turkish authorities to take energetic measures to improve the situation and restore order in the province of Kosovo. The Serbian demands were as follows: to disarm the Albanians or allow Serbs to arm themselves, reinforce garrisons with troops from remote parts of the Empire, ready to take harsh measures, remove incompetent ones and appoint energetic officials to establish the rule of law with the use of the army, arrest and punish of the Albanians criminals, among whom was Isija Feratagić. The Serbian demands were supported by Russia because they were not in contradiction with the established agreement signed with Austria-Hungary in $1897 .{ }^{34}$

Russia planned greater engagement in the protection of the Serbian people in Old Serbia, so it decided to open its consulate in Mitrovica. This decision caused even greater dissatisfaction among the Albanians, whose leader Isa Boljetinac publicly said that he would kill the Russian consul. The determination of Boljetinac to persevere in his intention was noticed by Austro-Hungarian agents who claimed that in that way a great service would be done to the Sultan. They also said that Russia should not be feared and that the murder of its consul would not provoke a great reaction. The Austro-Hungarians had a great influence on the ground, which encouraged the Albanians to commit new crimes. Mustafa Aga, the father of the murdered Muhammad and Elez Aga, a prisoner in Skopje, gathered 1,500 people and threatened to damage the railway between Vučitrn and Mitrovica, demanding the release of his son

33 AS, MID PPO, 1901, line 28, Pov. № 356, Consul S. Avramović - M. Vujić, Minister of Foreign Affairs, Priština, December 18, 1901; Peruničić, 1988, p. 125.

34 AS, MID PPO, 1902, line 26 (XIII), PP Br. 3051, Minister of Foreign Affairs - to the Embassy in Constantinople, Belgrade, August 14, 1902; Diplomatic Correspondence of the Kingdom of Serbia, 1933, no. while. 180, p. 263-266, no. while. 181, p. 266-270, no. while. 183, p. 272-273; Ћоровић, 1992, р. 25; Самарџић, 1989, p. 263; Јагодић, 2009, p. 336. 
from prison. At the same time, Isija Feratagic forced Mitrovica's archpriest Jovan and prominent Serbs to ask the governor to release him from guilt for the murder of Đorđe Sterđević. ${ }^{35}$ About five hundred Albanians from Drenica came to the aid of Mustafa Aga. They caused a breakdown on the railway, so Šemsi paša was given the task to deal with them and catch Mustafa Aga, Isija Feratagić and Šaban Kopriva, but he did not succeed. The first escaped to the Peć kaza, the second went to Lab via Vučitrn, while the third escaped in front of the army. Šemsi paša managed to capture only the brother of Isija Feratagić and Šerif Kučica and escorted them to Skopje. ${ }^{36}$

The tyranny of Isija Feratagić and other oppressors reached its peak at the beginning of the 20th century. The situation forced Serbs to complain to the Turkish authorities, the Government in Belgrade, but also to the representatives of foreign countries. The poor position of the Christian population led to greater engagement of the great powers, which were guided by personal interests. Their engagement forced Porta to accept the implementation of certain reforms and to deal with the opponents of the new situation. The first to be hit were the tyrants who committed a large number of murders. One of them was Isija Feratagić, who lost his primacy among the Albanians, and Isa Boljetinac imposed himself as the leader. The political issues related to the opening of the Russian consulate in Mitrovica and the implementation of the reform action pushed Isija Feratagić into the background, who, due to personal motives and the lowest interests, has long influenced the position of the Serbian people in Mitrovica and its surroundings.

\begin{tabular}{ll}
\hline UNPUB- & Archives of Serbia - Ministry of Foreign Affairs, Political Department \\
LISHED & Archives of Serbia - Ministry of Foreign Affairs, Political and Education De- \\
SOURCES & partment
\end{tabular}

PUBLISHED Diplomatic correspondence of the Kingdom of Serbia, book one. (1933). BelSOURCES grade: State Printing House of the Kingdom of Yugoslavia.

Peruničić, B. (1985). Letters of Serbian consuls from Pristina 1890-1900. Belgrade: Narodna knjiga.

35 AS, MID PPO, 1902, line 26 (XIV), Pov. № 128, Consul S. Avramović - P. Velimirović, Deputy Minister of Foreign Affairs, Priština, August 30, 1902.

36 AS, MID PPO, 1902, line 26 (XV), Pov. № 140, Consul S. Avramović - M. Vujić, Minister of Foreign Affairs, Priština, September 12, 1902. 
Perunicic, B. (1988). Testimony on Kosovo 1901-1913. Belgrade: Naučna knjiga.

REFERENCES Батаковић, Д. Т. (1991). Косово и Метохија у српско-арбанашким односима. Приштина-Горњи Милановац: Јединство-Дечје новине.

Зарковић, В. (2014). Критско питање и прилике у Косовском вилајету. Баштина, св. 37, 123-135.

Зарковић, В. (2015). 3бор Арбанаса у Пећи 1899. године и његове последице. Баштина, св. 38, 79-92.

Зарковић, В. (2021). Деловање Исе Бољетинца уочи отварања руског конзулата у Косовској Митровици. Баштина, св. 51, 425-447.

Јагодић, М. (2009).Српско-албански односи у Косовском вилајету (18781912). Београд: Завод за уџбенике.

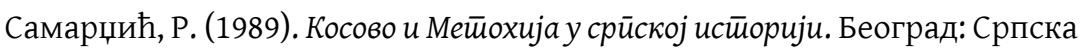
књижевна задруга.

Секулић, В. (2005). Убиство Ђорђа Стерђевића (Етничко чишћење и немоћ дипломатије). Баштина, св. 18, 259-272.

Стојанчевић, В. (1994). Друштвено-политичке прилике међу Арбанасима у Косовском вилајету на почетку XX века и арбанашки отпор против турских рефорама 1902/1903. године. Срби и Арбанаси 1804-1912. Нови Сад: Прометеј, 207-244.

Ћоровић, В. (1992). Односи између Србије и Аустроугарске у ХХ веку. Београд: Библиотека града Београда.

ВЕСНА С. ЗАРКОВИЋ

ИНСТИТУТ ЗА СРПСКУ КУЛТУРУ - ПРИШТИНА / ЛЕПОСАВИЋ

Слабљење Османског царства крајем XIX и почетком XX века негативно се одразило на положај српског становништва Косовског вилајета. Лошој ситуацији доприносили су и поступци Арбанаса који су били у тесној спрези са турским властима. Сва села, све вароши и варошице у Старој Србији, насељене Турцима и Арбанасима, као и мешовите средине, имале су бројне насилнике који су се истицали по својим злоделима. Један од таквих, поред осталих, који су утицали на збивања у Митровици и околини, био је Исија Фератагић. Конзул из Приштине Сима Аврамовић је наводио да се Фератагићу ставља на терет неко- 
лико убистава међу којима и Бећир аге Ћоровића, Малић ठега Призренца, заптијског јузбаше, два отпуштена војника из Сјенице, Глигорија Костића и Ђорђа Стерђевића. Поред убистава, он је свакодневно претио Србима, прогонио их, уцењивао, глобио, пресретао на путевима и заробљавао. Његова злодела су их неретко доводила у ситуацију да, под притиском, напусте своја огњишта и пронађу уточиште у Краљевини Србији.

Турске власти су често ठиле незаинтересоване да спрече арठанашке изгреде, а војне интервенције су углавном прерастале у сукоб војске и Арбанаса. У немогућности да даље подносе терор Срби из Митровице су више пута слали жалбе мутесарифу, валији и Порти. Зठог сличних проблема исто је реаговао и српски народ широм Старе Србије, који је уз подршку Владе из Београда и представника Русије небројано пута упућивао жалбе турским властима и султану у Цариграду, као и представницима великих сила. Под њиховим утицајем Порта је била приморана да прихвати спровођење реформи. Исија Фератагић који се у свом деловању руководио личним интересима и најнижим поривима потиснут је у други план, а водећу улогу у овом крају преузео је Иса Бољетинац.

КљУчнЕ РЕчи: Срби, Арбанаси, Исија Фератагић, Митровица, злочини, турске власти.

Овај чланак је објављен и дистрибуира се под лиценцом Creative Commons Ауторство-Некомерцијално Међународна 4.0 (CC BY-NC 4.0 |

https://creativecommons.org/licenses/by-nc/4.0/).

This paper is published and distributed under the terms and conditions of the Creative Commons Attribution-NonCommercial International 4.0 licence (CC BY-NC 4.0 | https://creativecommons.org/licenses/by-nc/4.0/). 